Original Article

Open

\title{
Detecting price artificiality and manipulation in futures markets: An application to Amaranth
}

Received (in revised form): 7th May 2012

\begin{abstract}
Atanu Saha
is Senior Vice President and Head of NY Office of Compass Lexecon. Dr Saha has served as an expert in many prior matters, and he specializes in the application of economics and finance to complex business litigation. He was a tenure-track professor at Texas A\&M University where he taught PhD-level courses in econometrics and applied economics. He is the recipient of the Graham Dodd Award for financial research. Dr Saha holds a PhD from the University of California, Davis, and an MA from the University of Alberta, Canada.
\end{abstract}

\section{Hans-Jürgen Petersen}

is a Vice President at Compass Lexecon. He has experience in economic litigation matters across a wide spectrum of industries and has testified on issues related to statistical sampling. Prior to Compass Lexecon, he taught mathematics and statistics at Loyola University of Chicago. Dr Petersen holds a PhD in mathematics from the University of Wisconsin - Milwaukee.

Correspondence: Atanu Saha and Hans-Jürgen Petersen, Compass Lexecon, 156 West 56th Street, 19th Floor, New York, NY 10019, USA

E-mails: asaha@compasslexecon.com; hpetersen@compasslexecon.com

The first author served as an expert witness in the Amaranth litigation.

ABSTRACT In this article we propose a general method to test whether economic data support the claim of futures market manipulation. We examine the question of whether or not Amaranth manipulated the market for natural gas futures using three alternative methods. The first is our contribution to the existing body of literature on the analysis of manipulation claims. The subsequent two have previously been discussed in the literature. All three methods yield the same result: economic data on futures prices and Amaranth's trades do not support the claim that Amaranth manipulated the natural gas futures market in 2006 . Journal of Derivatives \& Hedge Funds (2012) 18, 254-271. doi:10.1057/jdhf.2012.7; published online 21 June 2012

Keywords: manipulation; futures; natural gas

The online version of this article is available Open Access

\section{INTRODUCTION}

The history of futures trading dates back to the end of the American Civil War, when contracts for the delivery of grain were made into transferable contracts that were frequently used to offset each other. Since then, the futures market has expanded greatly in depth and scope, covering a wide range of commodities and financial products. It appears that with the proliferation of futures, there has been a corresponding increase in claims of manipulation in these markets, particularly in 
recent years. Some examples of litigation matters involving manipulation claims in futures markets include copper (In re Sumitomo Copper Litig., 1998, 1999, 2000, 2001), treasuries (Pacific Investment Management Company LLC and PIMCO Funds v. Hershey, 2010), natural gas (Hershey v. Energy Transfer Partners L.P., 2010; In re Natural Gas Commodity Litig., 2004, 2005, 2006; In re Amaranth Natural Gas Commodities Litig., 2008, 2009, 2010), milk (Anderson v. Dairy Farmers of America, Inc., 2010), silver (In re Commodity Exchange, Inc., Silver Futures and Options Trading Litig., 2011), platinum (In re Platinum and Palladium Commodities Litig., 2010), palladium (In re Platinum and Palladium Commodities Litig., 2010), and crude oil (CFTC v. Parnon Energy Inc., 2011).

In this article we propose a general method to test whether economic data support the claim of futures market manipulation. We illustrate our approach by applying it to the case of Amaranth Advisors LLC, which faced allegations of natural gas futures manipulation. Amaranth Advisors LLC, founded in 2000, was a multi-strategy hedge fund. It engaged in trading of natural gas futures, among other instruments. Following a steep decline in natural gas prices in August and September of 2006, Amaranth's futures positions suffered large losses. By mid-September, Amaranth was forced to transfer its energy portfolio to Citadel LLC and JPMorgan Chase and to close down the fund.

The question as to whether or not Amaranth manipulated natural gas futures prices in 2006 generated considerable controversy. While the Senate Permanent Subcommittee on Investigations (PSI) found that 'Amaranth's 2006 positions in the natural gas market constituted excessive speculation', the US Commodity Futures Trading Commission's (CFTC) Acting
Chairman Walter Lukken concluded that '... analysis of Amaranth trading data failed to conclude that Amaranth's trading was responsible for the spread price level observed during 2006' (Lukken and Dunn, 2007; US Senate PSI, 2007). Furthermore, a class-action lawsuit alleged that Amaranth manipulated the prices of 14 NYMEX futures contracts (the March 2006 through April 2007 futures contracts), thereby inflating winter-summer price spreads (In re Amaranth Natural Gas Commodities Litig., 2008). ${ }^{1}$

Most prior empirical studies on manipulation have examined price movements of the commodity or commodities at issue and not the trades of the alleged manipulator. This is because data on a hedge fund's positions and trades in any asset class are highly proprietary and are virtually impossible to acquire. However, the Amaranth matter was an exception. The Senate investigation yielded data on Amaranth's natural gas futures positions and trades. This data set provides a unique opportunity to empirically test the manipulation claims using actual data on the alleged manipulator's trades and their potential impact on prices.

In this article, we examine the question of whether or not Amaranth manipulated the market for natural gas futures using three alternative methods. The first is our contribution to the existing body of literature on the analysis of manipulation claims. The subsequent two have been discussed in the finance literature and serve as a robustness check of the results obtained using our approach. All three methods yield the same result: economic data on futures prices and Amaranth's trades do not support the claim that Amaranth manipulated the natural gas futures market in 2006. 


\section{THE RELEVANT LITERATURE}

Markham (1991) reviews historical manipulation in the commodity futures markets, the role of the Commodity Exchange Act (CEA), creation of the CFTC and manipulation cases brought by CFTC. Markham argues that while manipulation may take the form of rumors or false information and rigged trades, 'capping' or 'pegging', the most significant form is market power manipulation, including 'corners' and 'squeezes'. Fischel and Ross (1991-1992) provide an excellent overview of the relevant literature.

Several authors have recognized that there is little consensus on the definition of 'manipulation'. For example, Kolb and Overdahl (2007, p. 58) write:

One curious feature of the Commodity Exchange Act, and the regulations promulgated under the Act, is that 'manipulation' is referred to nearly 100 times without ever once being defined. The lack of a definition is not surprising, because the meaning of the word is so broad. Attempts to precisely define the term inevitably dissolve into circular logic: a manipulated price is an artificial price; an artificial price is one that has been manipulated.

In light of this perceived circularity in defining manipulation, Perdue (1987-1988) proposes a definition that focuses on whether the conduct of the party involved is reasonable, as opposed to focusing on the outcome. The article defines manipulation as conduct that would be uneconomical or irrational, absent manipulative intent.

By contrast, a number of studies, rather than attempting to define price artificiality or interpreting intent, have instead examined whether the alleged manipulator's trades actually affected futures prices. In his book, Pirrong (1996) proposes an economic model of manipulation and discusses the conditions that facilitate manipulation. In a subsequent article, Pirrong (2004) sets out a number of econometric tests to detect manipulation. These tests examine the empirical patterns of commodity flows and the relationship between spot and futures prices. Pirrong (2004) applies his methodology to the specific case of Ferruzzi soybean manipulation claim and concludes that soybean futures prices in the Chicago area were artificial as a result of Ferruzzi's manipulative activities in 1989.

Marthinsen and Gai (2010a) used a Granger causality model to analyze whether Amaranth's trades affected the prices of natural gas futures in 2006. In a follow-up article, the authors examined whether Amaranth's spread trading affected prices of calendar spreads, particularly the winter-summer spreads (Marthinsen and Gai, 2010b). In both papers, Marthinsen and Gai do not find evidence that Amaranth engaged in manipulation.

In this article, we contribute to the existing literature by proposing a method that allows the investigator to examine both whether prices were artificial and whether the alleged manipulator's trades caused any price artificiality in the futures market. This methodology essentially involves creating a model to explain futures prices using market fundamentals and then examining the correlation between the 'errors' (that is, the difference between actual and model-predicted prices) and the alleged manipulator's trades. We test the robustness of our results by applying Pirrong's spot-future price relationship test and Marthinsen and Gai's Granger model to the data on Amaranth's trading and natural gas futures prices. 
In the next section, we set out our proposed methodology. In the subsequent section, we discuss Pirrong's economic and econometric model of manipulation and apply it to the natural gas futures prices at issue. In the penultimate section, we undertake a Granger causality analysis, applying it not only to individual contract prices and price spreads, but also to price indices. The final section contains concluding comments.

\section{DETECTING PRICE ARTIFICIALITY AND MANIPULATION}

\section{A general two-step approach}

As noted earlier, defining price artificiality based on manipulation alone necessarily creates a circular logic: 'A manipulated price is an artificial price; an artificial price is one that has been manipulated' (Kolb and Overdahl, 2007, p. 58). Consequently, in this article, we propose a two-step approach: first, we examine the presence of price artificiality, and second, we test for manipulative effect. These two steps are distinct, although complementary.

In the first step, we define prices as artificial when they are not explained by market fundamentals. Clearly, the fundamental supply and demand factors that determine prices vary by commodity. For example, in the next subsection, we will discuss the specific supply and demand factors that affected natural gas futures prices in 2006. Generally, one should be able to examine the prices of the futures contracts at issue through a regression model that has the market fundamental factors as regressors, that is, right-hand-side variables. The residuals from this regression model reflect the effect on prices of factors unrelated to supply and demand fundamentals. If prices are indeed artificial, one will find statistically significant residuals during the alleged manipulation period. In other words, the test for statistically significant residuals from a market fundamental-based regression is the test for price artificiality.

However, a few caveats are in order. First, the efficacy of the approach in detecting price artificiality depends critically on correctly identifying the relevant market fundamental variables explaining commodity prices. If one or more key variables are omitted from the regression model specification, then the omission will be reflected in the residuals, leading to potentially erroneous conclusions regarding price artificiality.

Second, one needs to be cognizant about the data limitations of the variables reflecting market fundamentals. While it is true that most demand and supply factors are observable, a key variable that is almost always unobservable is the market participants' expectations about the future values of the demand and supply factors. For example, in the case of natural gas futures, the supply of natural gas in the United States is influenced by the incidence of hurricanes in the Gulf of Mexico and the shut-in production caused by hurricanes. While data on production disrupted by hurricanes are readily available and can be incorporated in the regression model, it is far more difficult to capture, for example, market participants' expectations about an approaching tropical storm and its likelihood of becoming a supplydisrupting hurricane. In the absence of data on market participants' subjective assessments about the future changes in demand and supply factors, the explanatory power of the regression model can be limited, leading to possibly false inferences about price artificiality. 
Because of these limitations, an inquiry into price artificiality cannot be viewed in isolation. It has to be examined in conjunction with an examination of the trading pattern of the alleged manipulator, which is the second step in our proposed two-step approach. In particular, the second step involves examining whether the regression residuals from the first step are positively correlated with the alleged manipulator's trades. If the alleged manipulator's buy-trades pushed up prices - leading to large positive regression residuals - then those residuals would be positively correlated with the trades. Conversely, if the alleged manipulator's large sell-trades pushed down prices, then that would yield large negative residuals, which would also be positively correlated with the alleged manipulator's trades. Standard tests can be performed to examine the statistical significance of the correlations.

It is important to recognize that this residualtrade correlation analysis is meaningful because the regression model contains variables reflecting market fundamentals and not the alleged manipulator's trades. ${ }^{2}$ Thus, the effect of the manipulator's trading activities, if any, would be necessarily reflected in the prices 'unexplained' by the model, that is, in the regression residuals.

Furthermore, while a statistically significant positive correlation between the price-model residuals and the trades can suggest manipulation, it does not imply that the alleged manipulator's trades 'caused' the price artificiality. Correlation, although necessary, is not a sufficient condition for causality. However, a large and statistically significant positive correlation would suggest that, during the relevant period, prices deviated from market fundamentals, which, in turn, is not inconsistent with the proposition that the alleged manipulator's trades caused prices to be artificial.

\section{Market conditions in 2006}

In this subsection, we illustrate our approach through its application to the data on Amaranth's trades. The first step entails construction of a regression model for natural gas futures prices. However, before listing the demand and supply factors that would constitute the explanatory variables in the model, it might be instructive to discuss the unique conditions that prevailed in the natural gas market in 2006. This discussion provides a useful backdrop for identifying the key demand and supply variables for the regression model of natural gas futures prices.

Because the plaintiffs' principal claim in the Amaranth litigation was that its trades affected the winter-summer price spreads, we focus on the behavior of the winter-summer price spreads of natural gas futures. The year 2006 was unusual not only for natural gas but also for related energy products, such as crude oil and heating oil. The levels of wintersummer price spreads for these three energy products for the years 2000-2009 are shown in Table 1. The average price spreads, excluding 2006, are shown at the bottom of this table. The fact that the winter-summer price spread for natural gas futures was unusually high in 2006 is clearly apparent from the table: it was US $\$ 3.15$ in 2006 , which was more than four times higher than the average for the years excluding 2006. However, it is also evident from the table that the price spread for heating oil was four times higher in 2006 relative to the other years. Crude oil is typically cheaper in winter, with the average winter-summer spread being $\$ 0.21$ for the years $2000-2009$, excluding 2006. Yet in 2006, the price spread of crude oil was positive and remarkably high at $+\$ 2.44$. 
Table 1: Average historical winter-summer futures price spread over alleged manipulation period days

\begin{tabular}{lrrr}
\hline Year & NG & \multicolumn{1}{c}{ HO } & \multicolumn{1}{c}{$C L$} \\
\hline 2000 & 0.10 & -0.02 & -2.50 \\
2001 & 0.39 & 0.02 & -0.81 \\
2002 & 0.57 & 0.03 & -0.76 \\
2003 & 0.20 & -0.01 & -2.31 \\
2004 & 0.59 & 0.01 & -1.99 \\
2005 & 1.01 & 0.06 & 0.99 \\
$\mathbf{2 0 0 6}$ & $\mathbf{3 . 1 5}$ & $\mathbf{0 . 1 6}$ & $\mathbf{2 . 4 4}$ \\
2007 & 1.71 & 0.10 & 2.11 \\
2008 & 0.79 & 0.06 & -0.99 \\
2009 & 1.67 & 0.15 & 4.36 \\
Average ex. 2006 & 0.78 & 0.04 & -0.21 \\
\hline
\end{tabular}

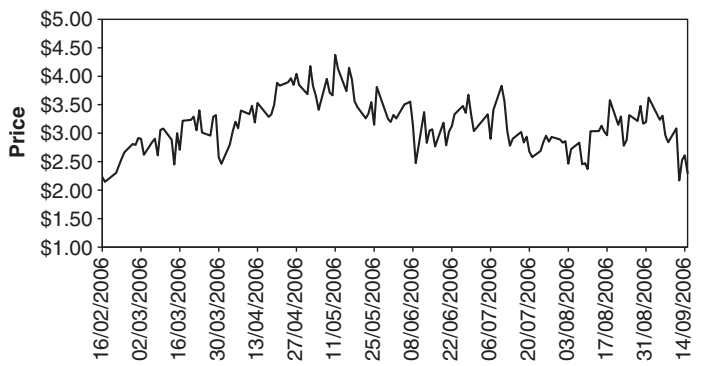

Figure 1: Winter-summer price spread index, 16/2/2006-15/9/2006.

The movement of winter-summer natural gas price spreads in the relevant period of 2006 is depicted in Figure 1. The underlying data for Figure 1 show that the price spreads increased through early May 2006 primarily because, while winter prices rose mildly, summer prices fell, causing the winter-summer spread to widen. During the period between early May and the end of August, the price spreads fell slightly, mainly as a result of generally declining winter prices. In September, the price spreads collapsed as both winter and summer prices fell rapidly, with winter prices evidencing a sharper decline.

Several key market fundamental factors explain the movement of winter-summer natural gas futures prices in 2006. First, the 2005-2006 winter was unusually warm, leading to lower demand for natural gas. The Energy Information Administration (EIA) reported in January 2006 that temperatures were between 22 and 41 per cent above normal for all Census divisions (EIA, 2006a). The warm weather continued through February and March 2006 (EIA, 2006b).

Second, the mild 2005-2006 winter created unusually high levels of natural gas inventory (Bryden et al, 2006; Dell and Goller, 2006). An analyst report noted that 'Naturally, the main factor fueling lower natural gas prices is the record surplus storage gas, which is currently ... 48 per cent above the five-year average, and 21 per cent above last year' (Covington et al, 2006, p. 22).

Third, analysts were expecting that the 2006 hurricane season, which was predicted to be very active, would strengthen natural gas prices, particularly the prices of the winter contracts. According to forecasts by Colorado State University's Tropical Meteorology Project released on 4 April 2006, '[t]he 2006 Atlantic hurricane season [was expected to be] much more active than the average 1950-2000 season' (Klotzbach and Gray, 2006). The National Oceanic and Atmospheric Administration (NOAA) also forecasted a very active hurricane season: 'The outlook calls for a very active 2006 season ... The main uncertainty in this outlook is not whether the season will be above normal, but how much above normal it will be. The 2006 season could become the fourth hyperactive season in a row' (National Oceanic and Atmospheric 
Administration, 2006, emphasis added).

NOAA's predictions turned out to be untrue. In early July, the EIA observed that natural gas futures prices were continuing to drop because of the inactive hurricane season (EIA, 2006c).

Late July and early August brought about a slight increase in natural gas prices due to triple digit temperatures (leading to a rare summer withdrawal of natural gas) and the threat of tropical storm Chris making landfall (Heim et al, 2006). Yet, soon after, the heat wave broke, and the threat of Chris dissipated. In mid-August, an analyst noted that the fear factor associated with the active hurricane season predictions had been supporting the natural gas futures curve; however, if the storms failed to materialize, gas prices would come under pressure in the fall (Adams et al, 2006).

Indeed, by the end of August, it became abundantly clear that the hurricane predictions for 2006 were grossly overstated. Since its inception in 1998, 2006 was the first year wherein NOAA over-forecasted hurricane activity both in May and August, and the first year since 2001 that no hurricanes struck the continental United States. This led to a sharp decline in natural gas futures prices in September, with winter prices falling more sharply than summer prices. A 4 October 2006 EIA report summarized the market dynamics contributing to the collapse of price spreads as follows:

The devastating impact last year's hurricanes had on oil infrastructure, along with forecasts of another strong hurricane season this year, led many oil market participants to buy additional contracts early in the year, with the expectation that prices could be much higher should hurricanes do similar damage this year or supply be disrupted overseas. However, when these expectations did not materialize, the selloff of contracts began and prices plummeted. (EIA, 2006d)

While the report references the dynamics in the oil market, the same fundamentals also affected the market for natural gas. This is corroborated by the data in Table 1, which suggest co-movements of spreads in related energy products.

\section{The data and regression model variables}

We first discuss the data on Amaranth's positions and trades in natural gas futures. We then discuss the explanatory variables for the regression analysis. As part of its Excessive Speculation in the Natural Gas Market report, the US Senate Permanent Subcommittee on Investigations (PSI) provided detailed information on Amaranth's daily positions on the NYMEX, Clearport and ICE natural gas derivatives market for Henry Hub delivery covering the time period January 2005-September 2006.

Included are Amaranth's positions in futures, swaps and options. The latter are expressed in futures equivalents (FEQs). The FEQs are available for 2006 only. For each day in 2006 and for each delivery month between March 2006 and October 2007, we aggregate the data into two measurements of Amaranth's positions: 'Futures Only' (this includes swaps) and 'Futures and Option FEQs'. Note that while a change in 'Futures Only' from one day to the next does imply a trade in a futures or swap contract on that day, the same is not true for a change in FEQs. The FEQ value might change due to changes in the option's volatility without 
any trade. However, in the absence of more detailed options data, we use change in Amaranth's FEQ positions as a proxy for its FEQ trades.

In order to address the co-movement of Amaranth's trades, and because of difficulties in allocating Amaranth's positions in a specific contract to a specific spread position, we constructed two winter-summer aggregate spread trade variables for Amaranth: (a) the sum of Amaranth's trades in the November 2006 through March 2007 contracts minus the sum of Amaranth's trades in the April 2006 through October 2006 contracts ('Trade 2006'); and (b) the sum of Amaranth's trades in the November 2006 through March 2007 contract minus the sum of Amaranth's trades in the April 2007 through October 2007 contracts ('Trade 2007'). In addition to using the two aggregate trade variables, we also examined Amaranth's individual spread trades, such as the January 2007-October 2006 trade and the March 2007-April 2007 trade.

Similar to the construction of the aggregate trade variables, we also constructed a corresponding spread price index. We defined the winter-summer spread price index as the volume-weighted prices of the November 2006 through March 2007 contracts minus the volume-weighted prices for the April 2006 through October 2006 contracts, with the volume being the number of contracts traded as reported by NYMEX.

Here we introduce an econometric model to explain natural gas futures prices for the 14 contracts at issue expiring in 2006-2007. Our review of industry publications and various empirical studies on energy prices reveals that most identify a common set of key demand and supply drivers of natural gas futures prices. We choose 10 explanatory variables reflecting market supply and demand fundamentals in a regression analysis of natural gas futures prices, including futures prices of competing energy products, forecasted energy use, inventory, weather and expected hurricane activity. Appendix A contains a detailed list of the 10 variables used in our model.

We use the same set of explanatory variables discussed above for the regression model for all 14 contracts. In each regression, we allow for the coefficient for each explanatory variable to be different for the summer (1 April-31 October) versus winter time period. For each contract, the regression is run using data for the time period 4 January 2006 through each contract's expiry date. We also ran the same regression to explain the summer and winter volume-weighted price indices; this index regression has the advantage of capturing the seasonal co-movement of contract prices. For each regression equation, we corrected for autocorrelation using the PraisWinsten method (Prais and Winsten, 1954; Greene, 1997). In Appendix B, we present the results of the regression for the summer and winter 2006 price indices. Details of the regression results for all 14 contracts are available from the authors upon request.

\section{Regression results and correlation analysis}

We find that the key demand and supply variables identified above explain a vast majority of the movement of the natural gas futures prices. Table 2 contains the adjusted $R$-squares for each of the 14 contracts and the two seasonal price indices. Table 2 shows that the regression model explains, on average, nearly 95 per cent of the price movements across the 14 contracts, and 
Table 2: Adjusted R-squares for the 14 contracts and seasonal price indices

\begin{tabular}{rlc}
\hline$\#$ & Contract or price index & $\begin{array}{c}\text { Adjusted } \\
\text { R-squares (\%) }\end{array}$ \\
\hline 1 & March 2006 contract & 96.1 \\
2 & April 2006 contract & 97.0 \\
3 & May 2006 contract & 96.7 \\
4 & June 2006 contract & 96.9 \\
5 & July 2006 contract & 94.6 \\
6 & August 2006 contract & 94.0 \\
7 & September 2006 contract & 91.2 \\
8 & October 2006 contract & 92.5 \\
9 & November 2006 contract & 90.9 \\
10 & December 2006 contract & 94.5 \\
11 & January 2007 contract & 94.6 \\
12 & February 2007 contract & 94.5 \\
13 & March 2007 contract & 94.8 \\
14 & April 2007 contract & 95.6 \\
15 & Summer 2006 price index & 91.7 \\
16 & Winter 2006-2007 price index & 90.5 \\
& & \\
& Average (1-14) & 94.6 \\
\hline
\end{tabular}

more than 90 per cent when prices are incorporated into the seasonal indices.

The small portion of the price movements that remains unexplained by market fundamentals are the 'residuals' in this regression analysis. A critical question is whether these residuals are correlated with Amaranth's trades during the alleged manipulation period. This is the second step of our proposed two-step approach. As discussed earlier, if indeed Amaranth's trades affected prices, then that impact would have been evidenced in the regression residuals because the model does not include any explanatory variable that reflects
Amaranth's trades. The exclusion of the latter and their potential impact on prices would thus be reflected in the regression errors, that is, the residuals.

Since we are interested in examining the correlation of Amaranth's spread trades with regression errors, we need to convert the residuals produced by our regression analyses into spread residuals. In order to do so, we simply take the difference between the residual for the winter contract and that for the summer contract. Accordingly, we define Amaranth's winter-summer spread trades as Trade 2006 and Trade 2007.

In Table 3, we report the correlation between the spread residuals and Amaranth's spread trades in individual contracts and for the wintersummer price spread index. The first seven are winter-summer spread prices, where the winter contract is represented by the January 2007 contract; in the next six, the winter prices are those of contracts November 2006 through March 2007, while the summer price for all six is represented by the October 2006 contract. Finally, we examine the winter-summer price spread index.

Table 3 shows that in all cases the correlation between regression errors and Amaranth's spread trades is generally extremely low or negative. We also undertook a formal test to examine whether any of these correlations is statistically significant. Of the 28 correlations listed, not a single one is statistically significant. ${ }^{3}$

Thus, our empirical findings show no evidence of impact of Amaranth's trades on the relevant natural gas futures contract prices. Rather, based on the results of our regression and correlation analysis, we conclude that market fundamentals were the drivers of the price of the 14 natural gas futures contracts at 
Table 3: Correlation between regression spread errors and Amaranth's spread trades, 4/1/2006-15/9/2006

\begin{tabular}{llccc}
\hline \# & Spread & $\begin{array}{c}\text { Number of } \\
\text { data points }\end{array}$ & Correlation between errors and Amaranth's trades \\
\cline { 4 - 5 } & & With FEQs & Without FEQs \\
\hline 1 & January 2007-April 2006 & 28 & 0.06 & 0.14 \\
2 & January 2007-May 2006 & 46 & -0.01 & -0.01 \\
3 & January 2007-June 2006 & 68 & -0.15 & -0.16 \\
4 & January 2007-July 2006 & 89 & -0.21 & -0.15 \\
5 & January 2007-August 2006 & 107 & -0.23 & -0.20 \\
6 & January 2007-September 2006 & 130 & -0.12 & -0.09 \\
7 & January 2007-October 2006 & 141 & -0.04 & -0.02 \\
8 & November 2006-October 2006 & 141 & 0.04 & 0.04 \\
9 & December 2006-October 2006 & 141 & 0.01 & -0.01 \\
10 & January 2007-October 2006 & 141 & -0.04 & -0.05 \\
11 & February 2007-October 2006 & 141 & -0.06 & -0.06 \\
12 & March 2007-October 2006 & 141 & -0.08 & 0.08 \\
13 & March 2007-April 2007 & 141 & 0.03 & 0.01 \\
14 & Winter-summer price spread index & 141 & 0.01 & \\
\hline
\end{tabular}

issue and that there is no causal impact of Amaranth's spread trades on those price spreads. In the next two sections, we examine whether our findings are corroborated using two alternative approaches that exist in the literature.

\section{PIRRONG'S ANALYSIS OF A MANIPULATION CLAIM}

Pirrong argues that a manipulation of a commodity futures market is profitable when a trader owns large long futures positions, and the marginal cost of transporting the commodity increases as short traders are forced to make more deliveries. He posits that ' ... by calling for too many deliveries of the commodity (equivalently, by liquidating too few contracts), the large long induces shorts to repurchase their remaining positions at artificially high prices... [A] cornerer artificially increases demand for the commodity at the delivery point during the delivery period in order to earn a supercompetitive profit' (Pirrong, 2004, p. 34).

In his 2004 paper, Pirrong tests whether Ferruzzi manipulated soybean futures in the May contract. To test whether the price of the May 1989 futures contract was manipulated, Pirrong uses historical price data to model the normal relationship between May soybean contract prices and non-deliverable spot prices (central Illinois) using regression analysis. Pirrong then cumulates the regression errors for the relevant 
period in May 1989 and tests whether the magnitude of these cumulated residuals is statistically significant. He then concludes that the statistical significance of the cumulated residuals is consistent with the claim of manipulation by Ferruzzi.

In applying Pirrong's framework, we have confined the test of artificiality to the relationship between futures and spot prices. If the manipulation claim were true, then one would have observed that the historical relationship between spot and futures prices for natural gas futures would have ceased to exist during the class period in 2006. In other words, the cumulative residuals (from the regression of futures on spot prices) would have been statistically significant during the period in which Amaranth's trades allegedly affected the futures prices.

In undertaking the analysis of spot and future price, we have compared the prices of Henry Hub rolling front month, first-deferred month and second-deferred month natural gas futures contracts to the spot prices at various locations: the delivery location at Henry Hub and the non-delivery locations at Alberta, El Paso and an average of West Coast locations. ${ }^{4}$ This comparison is undertaken by regressing the relevant daily log-return of futures prices on the daily log-returns of spot prices, for the period 16 February-31 August $^{5}$ for each of the years 2000-2009, excluding 2006. These regressions yield the predicted futures price returns and the resulting out-of-sample regression residuals for 2006. We then test for the statistical significance of the cumulative residuals for the February through August period in $2006 .{ }^{6}$

Table 4 shows the cumulated residuals and corresponding $t$-statistics for the 12 regressions. None of the $t$-statistics for the cumulated residuals (cumulated through 31 August 2006) is statistically significant (since they are all less than 1.96 in absolute value). These results are inconsistent with the claim of manipulated natural gas futures prices.

Since the cumulated residuals come from outof-sample forecasts for 2006 using a regression model that excludes data for 2006, a possible source of statistical significance of the residuals could be a structural break in $2006 .^{7}$ In fact, the data in Table 1 seem to indicate this. Two observations are in order here. First, while Table 1 data seem to suggest that all energy prices (including natural gas) experienced a structural break in 2006, the relationship between spot and futures prices for natural gas need not have changed structurally in 2006. Second, even if one admits the possibility of structural break in

Table 4: Cumulative residuals as of $31 / 8 / 2006$

\begin{tabular}{|c|c|c|c|c|c|c|}
\hline \multirow[t]{2}{*}{ Spot location } & \multicolumn{2}{|c|}{ Front month } & \multicolumn{2}{|c|}{ Second month } & \multicolumn{2}{|c|}{ Third month } \\
\hline & $C R$ & $t$-stat & $C R$ & t-stat & $C R$ & $t$-stat \\
\hline Henry Hub & -0.18 & -0.51 & -0.21 & -0.62 & -0.17 & -0.53 \\
\hline Alberta & -0.18 & -0.52 & -0.20 & -0.61 & -0.16 & -0.52 \\
\hline El Paso & -0.22 & -0.60 & -0.23 & -0.68 & -0.19 & -0.60 \\
\hline West Coast average & -0.20 & -0.54 & -0.22 & -0.64 & -0.18 & -0.56 \\
\hline
\end{tabular}


the spot-futures price relationship, that break would have been reflected in the statistical significance of the cumulated residuals for 2006. The results in Table 4 show that this is not the case. However, if the cumulated residuals were statistically significant, the spot-future price relationship test would have been incapable of discerning the source of the statistical significance: it could have been either structural break in 2006 and/or the effect of Amaranth's trades.

We have undertaken two variations of the analysis reported in Table 4 to verify the robustness of our results. The cumulative residuals are insignificant for every spot price if the period is extended to 15 September 2006. The cumulative residuals are also insignificant for every spot price when the dependent variable is a volume-weighted index of summer and winter futures prices.

\section{AN APPLICATION OF GRANGER ANALYSIS}

\section{Overview of Granger analysis}

The Granger causality test is concerned with testing whether past changes in a time series variable $X$ are useful in predicting the current change in another time series variable $Y$. If the answer is affirmative, then the experimenter concludes that ' $X$ Granger-causes $Y$ '. In the context of allegations that Amaranth manipulated prices, an implementation of the Granger causality test is a regression analysis to examine whether the past changes in Amaranth's winter-summer spread trades are associated with the current changes in winter-summer price spreads. If the allegations were true and Amaranth had manipulated the market, one would expect to find this association to be positive and statistically significant.

The Granger causality test has its limitations. Spurious Granger causality can be inferred when both variables $X$ and $Y$ have a common (exogenous) cause $Z$ that is absent from the regression equation. In this case, the test could erroneously conclude Granger causality between $X$ and $Y$ (Hood III et al, 2008; Hartwig, 2009). Classic examples highlighting this issue can be found in several earlier studies (for example, sunspots causing GNP and/or prices [Jevons, 1884], or GNP and/or prices causing sunspots [Sheehan and Grieves, 1982; Chowdury, 1987]).

We follow the Granger causality specification set forth in Marthinsen and Gai (2010a), who base their approach on the work of Hartzmark (1991), Wang (2001), and Sanders et al (2004)

$$
R_{t}^{c}=\alpha+\sum_{i=1}^{m} \gamma_{i} R_{t-i}^{c}+\sum_{j=1}^{n} \beta_{i} \Delta A P_{t-j}^{c}+\varepsilon_{t}
$$

where $R_{t}^{c}=\ln \left(P_{t}^{c}\right)-\ln \left(P_{t-1}^{c}\right)$ is the $\log$ return for contract $c$ at date $t$, and $P_{t}^{c}$ is the settlement price for contract $c$ on trade date $t$. For example, $P_{3 \text { Jan } 2006}^{\text {Oct } 2006}$ represents the settlement price on 3 January 2006 for the October 2006 natural gas futures contract. Finally, $\Delta A P_{t-j}^{c}$ is the first difference of Amaranth's position for contract $c$ over time period $t-j$.

\section{Results of Granger causality analysis}

We perform Granger causality tests on three spreads: January 2007-October 2006, March 2007-April 2007 and winter-summer index price spreads. In each case, the Granger regression is run using data for the period 16 February through 15 September 2006. For the first two, the key regressor is the lagged value of Amaranth's corresponding spread trades; for 
Table 5: Granger regression of price spreads and Amaranth's spread trades

\begin{tabular}{|c|c|c|c|c|}
\hline \multirow[t]{2}{*}{ Winter-summer price spread variable } & \multicolumn{2}{|c|}{ With FEQs } & \multicolumn{2}{|c|}{ Without FEQs } \\
\hline & Coefficient & $t$-stat & Coefficient & $t$-stat \\
\hline January 2007-October 2006 & -0.35 & -2.14 & -0.29 & -1.69 \\
\hline March 2007-April 2007 & -0.09 & -0.78 & -0.05 & -0.40 \\
\hline Winter-summer price spread index & -0.04 & -0.13 & 0.04 & 0.15 \\
\hline
\end{tabular}

the price index, the key regressor is Amaranth's lagged aggregate trade variable, Trade 2006. In Table 5, we report the estimated coefficient of the lagged Amaranth trade variable. None of the Granger causality tests shows an estimated coefficient that is both positive ${ }^{8}$ and statistically significant.

To verify the robustness of our analysis, we performed Granger causality tests for all possible winter-summer price spread combinations. Each of the five winter contracts at issue (November 2006-March 2007) was paired with each of the eight summer contracts at issue (April 2006-October 2006 plus April 2007), resulting in 40 combinations. For the right-hand-side variables, we used Trade 2006 if the summer leg of the spread belonged to summer 2006, and we used Trade 2007 if the summer leg was April 2007. None of the 40 Granger regressions yielded positive and statistically significant coefficient estimates.

In summary, we find no empirical evidence suggesting that Amaranth's trading in wintersummer spreads Granger-caused changes in winter-summer spread prices in 2006.

\section{CONCLUDING COMMENTS}

We have examined the question of whether or not Amaranth manipulated the market for natural gas futures using three alternative methods. After reviewing the existing body of literature, we have proposed a method that allows the investigator to examine both whether prices were artificial and whether the alleged manipulator's trades caused any price artificiality in the futures market. To test the robustness of our results, we have applied two additional approaches, the spot-future price relationship test and a Granger model, to Amaranth's trading data and natural gas futures prices. Application of all three approaches yielded the same conclusion: the evidence is not consistent with the proposition that Amaranth manipulated the market for natural gas futures in 2006.

In the class-action lawsuit, the plaintiffs had also alleged that Amaranth depressed the settlement prices of the March 2006, April 2006 and May 2006 contract prices by 'slamming the close' of these three expiring contracts. We have not addressed this issue here, although such an analysis would be a useful extension to this article. Analysis of the 'slamming the close' claims requires examination of the intra-day price and trade data. Furthermore, the methodology proposed in this article needs to be suitably modified to address intra-day trades and their potential impact on prices during the 30 -min settlement 
period of expiring contracts. We plan to extend the methodological framework that allows us to examine intra-day price manipulation claims in a subsequent study.

\section{ACKNOWLEDGEMENTS}

The authors are immensely grateful to Cecilia Seiden for her excellent research support. We wish to also acknowledge our gratitude to Carina Chambarry, Elizabeth Wall, Nicolas Shea and Hillel Kipnis for their invaluable assistance with research and data analytics and their thoughtful comments. We are extremely grateful to Mary Shen for her editorial assistance. The authors are also indebted to the reviewers for their helpful comments.

\section{NOTES}

1. In this litigation, the plaintiffs claimed the manipulation period to extend from 16 February through 15 September 2006 (the class period).

2. One might be inclined to combine the two steps in our approach by including the alleged manipulator's trades as a right-handside variable in the regression equation and testing for the statistical significance of the trade variable's coefficient. However, this approach introduces an endogeneity bias in the estimation since trades affect prices, and prices affect trades. The standard approach of using instrumental variables that are correlated with the trade variable but uncorrelated with the residuals is problematic here because it is virtually impossible to find a suitable instrumental variable that satisfies the required conditions and is also responsive to the issues at hand. In particular, a natural candidate for an instrumental variable is Amaranth's lagged trades. However, the lagged trade variable would not be an appropriate choice in the context of this application because the manipulation claim is that Amaranth's trades on any given day affected prices on that day, and not necessarily the subsequent day.

3. To check for robustness, we have also tested the correlation between regression spread errors and lagged Amaranth's spread trades $(t-1)$, and the correlation between regression errors and Amaranth's trades for individual contracts, and find our results to be robust.

4. Average of West Coast locations is constructed by Bloomberg, L.P.

5. We have started our analysis on 16 February, as that is the day the class action complaint alleges the manipulation began. We have chosen 31 August as the end date because after that date, natural gas futures prices fell sharply across almost all traded contracts. Thus, the cumulative residuals would likely be highest at the end of August 2006.

6. The $C R_{T}=\sum_{t=1}^{T} \hat{e}_{t}$, where $\hat{e}_{t}$ denotes the residual from the regression of the futures on the spot price on the $t$-th day. Let the root mean square of this regression be denoted by $\hat{\sigma}$. Then the $t$-statistic for testing the statistical significance of $C R_{T}$ is given by $C R_{T} /(\sigma \cdot \sqrt{T})$.

7. We are indebted to an anonymous reviewer for suggesting this point.

8. The importance of the sign of the coefficients within a Granger causality framework is documented in several earlier studies; see Marvell and Moody (1996), Sanders et al (2004, pp. 435-437), Marthinsen and Gai (2010a, p. 271). 


\section{REFERENCES}

Adams, D., Mariani, L. and Nuschler, G. (2006) Energy: Jefferies North American Natural Gas Weekly. Jefferies \& Company, Inc., 14 August.

Bryden, P., Shaw, G. and Kelly, F. (2006) Oil \& Gas Trusts: An Overview of Recent Natural Gas Price Weakness and Potential Implications for Distribution Levels. RBC Capital Markets, 24 March.

Chowdury, A.R. (1987) Are causal relationships sensitive to causality tests? Applied Economics 19(4): 459-465.

Covington, T., Scialla, M. and Pikul, C. (2006) US Natural Gas Market Update \& Outlook: Lowering 2006 Natural Gas Price Forecast to \$7.50. Edwards, 7 March.

Dell, B. and Goller, A. (2006) Bernstein EEPs: Lower Natural Gas Prices and Escalating Costs. Who is Best Positioned for Margin Compression? Bernstein Research, 19 April.

Energy Information Administration. (2006a) Natural Gas Weekly. EIA report, 19 January.

Energy Information Administration. (2006b) Natural Gas Weekly. EIA report, 27 April.

Energy Information Administration. (2006c) Natural Gas Weekly. EIA report, 7 July.

Energy Information Administration. (2006d) This Week in Petroleum. EIA report, 4 October.

Fischel, D.R. and Ross, D.J. (1991-1992) Should the law prohibit manipulation in financial markets? Harvard Law Review 105(2): 503-553.

Greene, W.H. (1997) Econometric Analysis, 3rd edn. Upper Saddle River, NJ: Prentice-Hall.

Hartwig, J. (2009) A Panel Granger-Causality Test of Endogenous vs. Exogenous Growth. Zurich, $\mathrm{CH}$ : KOF Swiss Economic Institute at ETH Zurich. KOF Working Papers, No. 231.

Hartzmark, M.L. (1991) Luck versus forecast ability: Determinants of trader performance in futures markets. Journal of Business 64(1): 49-74.

Heim, M., Mikhareva, J., Donohue, M. and Argiris, P. (2006) Weekly Gas Statistics: Natural Gas Futures Hit Three-Month High. Orion Securities, Inc., 4 August.

Hood III, M.V., Kidd, Q. and Morris, I.L. (2008) Two sides of the same coin? Employing Granger causality tests in a time series cross-section framework. Political Analysis 16(3): 324-344.

Jevons, W.S. (1884) Commercial crises and sun-spots. In: W.S. Jevons and H.S. Foxwell (eds.) Investigations in Currency and Finance. London, UK: Macmillan.

Klotzbach, P.J. and Gray, W.M. (2006) Extended range forecast of Atlantic seasonal hurricane activity and US landfall strike probability for 2006. Colorado State University, Department of Atmospheric Science, 4 April. http://hurricane.atmos.colostate.edu/Forecasts/ 2006/april2006/.
Kolb, R.W. and Overdahl, J.A. (2007) Futures, Options, and Swaps, 5th edn. Malden, MA: Blackwell Publishing.

Lukken, W. and Dunn, M. (2007) Written Testimony of Acting Chairman Walter Lukken and Commissioner Michael Dunn, Commodity Futures Trading Commission, Before the Permanent Subcommittee on Investigations, Committee on Homeland Security and Governmental Affairs, United States Senate. 9 July.

Markham, J.W. (1991) Manipulation of commodity futures prices - The unprosecutable crime. Yale Journal on Regulation 8(2): 281.

Marthinsen, J.E. and Gai, Y. (2010a) Did Amaranth advisors LLC engage in interday price manipulation in the natural gas futures market? Journal of Derivatives $\mathcal{E}$ Hedge Funds 15(4): 261-273.

Marthinsen, J.E. and Gai, Y. (2010b) Did Amaranth's absolute, relative and extreme positions affect natural gas futures prices, spreads and volatilities? Journal of Derivatives and Hedge Funds 16(1): 9-21.

Marvell, T.B. and Moody, C.E. (1996) Specification problems, police levels, and crime rates. Criminology 34(4): 609-646.

National Oceanic and Atmospheric Administration. (2006) NOAA: 2006 Hurricane Outlook. NOAA report, 22 May.

Perdue, W.C. (1987-1988) Manipulation of futures markets: Redefining the offense. Fordham Law Review 56(3): 345-402.

Pirrong, C. (1996) The Economics, Law, and Public Policy of Market Power Manipulation. Norwell, MA: Kluwer Academic Publishers.

Pirrong, C. (2004) Detecting manipulation in futures markets: The Ferruzzi soybean episode. American Law and Economics Review 6(1): 28-71.

Prais, S.J. and Winsten, C.B. (1954) Trend Estimators and Serial Correlation. Cowles Commission Discussion Paper no. 383.

Sanders, D.R., Boris, K. and Manfredo, M. (2004) Hedgers, funds, and small speculators in the energy futures markets: An analysis of the CFTC's Commitments of Traders reports. Energy Economics 26(3): 425-445.

Sheehan, R.G. and Grieves, R. (1982) Sunspots and cycles: A test of causation. Southern Economic Journal 48(3): 775-777.

United States Senate Permanent Subcommittee on Investigations, Committee on Homeland Security and Governmental Affairs. (2007) Excessive Speculation in the Natural Gas Market. Staff Report with Additional Minority Views. http://hsgac.senate.gov/public/_files/ REPORTExcessiveSpeculationintheNaturalGasMarket .pdf.

Wang, C. (2001) Investor sentiment and return predictability in agricultural futures markets. The Journal of Futures Markets 21(10): 929-952. 


\section{REFERENCED CASES:}

In re Sumitomo Copper Litigation, 182 F.R.D. 85 (S.D.N.Y. 1998).

In re Sumitomo Copper Litigation, 189 F.R.D. 274, 284 (S.D.N.Y.1999).

In re Sumitomo Copper Litigation, 104 F. Supp. 2d 314 (S.D.N.Y. 2000).

In re Sumitomo Copper Litigation, 194 F.R.D. 480 (S.D.N.Y. 2000).

In re Sumitomo Copper Litigation, 120 F. Supp. 2d 328 (S.D.N.Y. 2000).

In re Sumitomo Copper Litigation, 262 F. 3d 134 (2d Cir. 2001).

Pacific Investment Management Company LLC \& PIMCO Funds v. Hershey, 130 S. Ct. 1504, (2010).

Hershey v. Energy Transfer Partners, L.P., 610 F. 3d 239 (5th Cir. 2010).

In re Natural Gas Commodities Litigation, 337 F. Supp. 2d 498, 502 (S.D.N.Y. 2004).

In re Natural Gas Commodities Litigation, 231 F.R.D. 171, 181-182 (S.D.N.Y. 2005).

In re Natural Gas Commodities Litigation, 235 F.R.D. 241, 244 (S.D.N.Y. 2006).

In re Amaranth Natural Gas Commodities Litigation, 587 F. Supp. 2d 513 (S.D.N.Y. 2008).

In re Amaranth Natural Gas Commodities Litigation, 612 F. Supp. 2d 376 (S.D.N.Y. 2009).

In re Amaranth Natural Gas Commodities Litigation, $711 \mathrm{~F}$. Supp. 2d 301 (S.D.N.Y. 2010).

In re Amaranth Natural Gas Commodities Litigation, 269 F.R.D. 366 (S.D.N.Y. 2010).

Anderson v. Dairy Farmers of America, Inc., No. 08-4726, 2010 WL 3893601 (D. Minn. 30 September 2010).

In re Commodity Exchange, Inc., Silver Futures and Options Trading Litigation 775 F. Supp. 2d 1382 (S.D.N.Y. Filed on 8 February 2011).

In re Platinum and Palladium Commodities Litigation, No. 10-Civ.3617(WHP) (S.D.N.Y. filed 30 April 2010).

CFTC v. Parnon Energy Inc., No. 1:11-cv-03543 (S.D.N.Y. 24 May 2011).

\section{APPENDIX A}

\section{Regression Model Variables Used in Analysis of Natural Gas Futures Prices}

1. Futures prices of competing energy products: We use the prices of crude oil and heating oil futures;
2. Forecasted energy use: We use forecasts of daily energy demand through the Dominion Energy Index, contained in Platts Gas Daily;

3. Demand: We use a daily measure of US demand derived from data provided by Bentek;

4. Actual impact of hurricane activity: We use actual production loss figures due to hurricanes in the Gulf of Mexico produced by the Bureau of Ocean Energy Management, Regulation, and Enforcement;

5. Inventory: We measure the differential in existing storage level relative to the prior five-year average;

6. Inventory: We complement the measure of the differential in existing storage level introduced previously with a measure of storage injections and withdrawals derived from data provided by Bentek and the EIA;

7. Weather: We use a population-weighted average of heating and cooling degree days (HDD and CDD) for 16 major US cities, using HDD and CDD data from NOAA and population data from the US Census Bureau. We also use an HDD and CDD differential from the 15-year historical average. HDD and CDD are measures of temperature typically in winter and summer; they are widely used determinants of energy demand;

8. Weather forecast: We complement the measures of heating and cooling degree days introduced previously with a populationweighted average of the temperature forecasts for 16 major US cities, using Weather Services International (WSI) weather forecasts and population data from the US Census Bureau. 
9. Expected hurricane activity: We use forecasts of the ACE Index from the National Oceanographic and Atmospheric Association (NOAA) on the intensity of the upcoming hurricane season;
10. Other macro economic factors: We use the daily data on the level of the S\&P 500 index and also an index of the strength of the US dollar relative to a basket of other currencies.

\section{APPENDIX B}

Table B1: Regression coefficients of natural gas futures contracts price indices, 4 January 2006 - index expiry

\begin{tabular}{|c|c|c|c|c|}
\hline \multirow[t]{2}{*}{ Variables } & \multicolumn{2}{|c|}{ Summer index } & \multicolumn{2}{|c|}{ Winter index } \\
\hline & Coefficient & $t$-Stat & Coefficient & $t$-stat \\
\hline Intercept & -2.897 & -0.18 & 2.643 & 0.24 \\
\hline (1) Summer dummy & -1.901 & -0.11 & -8.965 & -0.64 \\
\hline \multicolumn{5}{|l|}{ (2) Competing products } \\
\hline Heating oil summer & -1.172 & -0.77 & -0.181 & -0.10 \\
\hline Heating oil winter & 1.637 & 0.69 & 3.612 & 1.70 \\
\hline Lag of heating oil summer & 1.818 & 1.18 & 4.738 & 2.62 \\
\hline Lag of heating oil winter & -1.763 & -0.82 & 0.995 & 0.47 \\
\hline Crude oil summer & 0.084 & 1.74 & 0.094 & 1.65 \\
\hline Crude oil winter & 0.063 & 0.89 & 0.009 & 0.15 \\
\hline Lag crude oil summer & -0.089 & -1.80 & -0.115 & -2.02 \\
\hline Lag crude oil winter & 0.076 & 1.13 & -0.046 & -0.75 \\
\hline \multicolumn{5}{|l|}{ (3) Forecasted energy use } \\
\hline Dominion energy index summer & 0.750 & 2.17 & 0.727 & 1.89 \\
\hline Dominion energy index winter & -0.170 & -0.36 & -0.429 & -1.19 \\
\hline Demand summer & 0.000 & 1.64 & 0.000 & 0.39 \\
\hline Demand winter & 0.000 & -0.41 & 0.000 & 1.70 \\
\hline \multicolumn{5}{|l|}{ (4) Production } \\
\hline Shut-in summer & 0.007 & 6.77 & 0.004 & 5.39 \\
\hline Shut-in winter & 0.005 & 1.63 & 0.002 & 3.60 \\
\hline Lag storage differential summer & -0.012 & -5.69 & -0.006 & -2.99 \\
\hline Lag storage differential winter & 0.001 & 0.44 & -0.002 & -2.57 \\
\hline Storage injections/withdrawals summer & -0.001 & -0.60 & -0.003 & -1.39 \\
\hline Storage injections/withdrawals winter & 0.002 & 1.20 & 0.000 & -0.04 \\
\hline
\end{tabular}


Table B1 continued

\begin{tabular}{|c|c|c|c|c|}
\hline \multirow[t]{2}{*}{ Variables } & \multicolumn{2}{|c|}{ Summer index } & \multicolumn{2}{|c|}{ Winter index } \\
\hline & Coefficient & $t$-Stat & Coefficient & $t$-stat \\
\hline \multicolumn{5}{|l|}{ (5) Weather } \\
\hline HDD summer & -0.159 & -2.69 & -0.028 & -0.49 \\
\hline HDD winter & -0.018 & -0.51 & -0.078 & -2.47 \\
\hline CDD summer & -0.101 & -1.88 & -0.042 & -0.64 \\
\hline CDD winter & 1.222 & 1.67 & 0.192 & 0.31 \\
\hline HDD differential summer & 0.172 & 2.88 & 0.005 & 0.09 \\
\hline HDD differential winter & -0.019 & -0.58 & 0.052 & 1.83 \\
\hline CDD differential summer & 0.084 & 1.78 & 0.009 & 0.16 \\
\hline CDD differential winter & -1.223 & -1.74 & -0.231 & -0.39 \\
\hline WSI weather forecast summer & 0.058 & 1.82 & 0.032 & 0.82 \\
\hline WSI weather forecast winter & -0.056 & -1.27 & -0.049 & -1.58 \\
\hline ACE index summer & 0.001 & 0.99 & 0.001 & 0.41 \\
\hline ACE index winter & $\mathrm{N} / \mathrm{A}$ & N/A & -0.003 & -0.15 \\
\hline \multicolumn{5}{|l|}{ (6) Economic variables } \\
\hline S\&P 500 index summer & 0.004 & 1.48 & 0.008 & 2.35 \\
\hline S\&P 500 index winter & 0.000 & -0.04 & -0.004 & -1.06 \\
\hline \multicolumn{5}{|l|}{ (7) Currency } \\
\hline US Trade weighted index summer & 0.047 & 0.72 & -0.041 & -0.60 \\
\hline US trade weighted index winter & -0.048 & -0.36 & 0.120 & 1.08 \\
\hline Adjusted $R^{2}$ & $91.74 \%$ & - & $90.50 \%$ & - \\
\hline Observations & 178 & - & 273 & - \\
\hline
\end{tabular}

Note: Regression results are available for individual spreads and contracts upon request.

This work is licensed under a Creative Commons Attribution-NonCommercial-

NoDerivative Works 3.0 Unported License. To view a copy of this license, visit http:// creativecommons.org/licenses/by-nc-nd/3.0/ 